\title{
Design and Exergy Analysis of a Thermal Power Plant Using Different Types of Turkish Lignite
}

\author{
Amirabedin Ehsan ${ }^{\mathrm{a}}$, M. Zeki Yilmazoglu ${ }^{\mathrm{b}}$ \\ Researcher at Department of Mechanical Engineering, \\ Faculty of Engineering, Gazi University, Ankara, Turkey \\ a ehsan.amirabedin@gmail.com, ${ }^{b}$ zekiyilmazoglu@gazi.edu.tr
}

\begin{abstract}
The purpose of this study is to design a $240 \mathrm{MW}_{\mathrm{el}}$ thermal power plant (TPP) to be operated with ten different types of Turkish lignite and fulfill an exergy analysis including the determination and comparison of the performance for each type of lignite. Additionally an examination of the effect of the ambient temperature on the power plant's exergy efficiency and calculation of the $\mathrm{CO}_{2}$ emissions of each lignite type is carried out. Exergy destruction of each component is investigated by using conservation of mass, conservation of energy and exergy destruction in an open system at steady state. Sivas Kangal lignite is selected for designing. Net energy and exergy efficiencies of the plant are calculated as 37.16 and $34.84 \%$ respectively. The analysis of the case study revealed that the boiler is the major source of exergy destruction with $299.10 \mathrm{MW}$ and $83.29 \%$ of the total exergy destruction of the overall plant. Another point is that, fuel consumption and $\mathrm{CO}_{2}$ emissions of the TPP increase with rising ambient temperature. It should be noted that, comparison between the performances and emission data of the power plants can provide useful data for the future coal-fired thermal power plants investments in Turkey.
\end{abstract}

Keywords: Thermal power plant; low rank lignite; exergy analysis; $\mathrm{CO}_{2}$ emissions.

\section{Introduction}

Despite the rapid developments in renewable energy utilization, it can be estimated that, fossil fuel dependency will continue for decades. Lignite is one of the most widely used fossil fuels in Turkey due to its vast reserves. According to IEA, approximately $26 \%$ of the total energy demand is met by lignite in Turkey. However, because of the environmental effects and combustion difficulties of the low grade lignite, an improved method for its better utilization is required. As a result, pre-treatment of coal is widely used for lowering the combustion emissions. Gasification applications of the lignites are still to be developed for integration to a combined cycle.

Researchers all around the world are carrying out exergy studies and have evaluated the performance of power plants to assess the main locations of the losses, in order to optimize the performance of the power plants. The most commonly used method for evaluating the efficiency of an energy-conversion process is the first-law analysis. Nevertheless, there is an increasing interest in the combined utilization of the first and second laws of thermodynamics, using such concepts as exergy, entropy generation and irreversibility in order to evaluate the efficiency with which the available energy is consumed (Kopac and Hilalci, 2007).

Kopac and Hilalci (2007) presented energy and exergy analysis of the Çatalağzı power plant and investigated the effect of ambient temperature on the power plant performance. Erdem et. al. (2009) performed a comparative analysis of the performance of nine thermal power plants under the control of governmental bodies in Turkey, from energetic and exergetic points of view. Oktay (2009) analyzed a modern coal-fuel power plant in Turkey using the exergy calculation. Ganapathy et. al. (2009) performed an exergy analysis on an operating $50 \mathrm{MW}_{\mathrm{e}}$ unit of lignite- fired steam power plant, aiming to find the energy efficiency and exergy efficiency of the power plant. The results revealed that maximum energy loss of $39 \%$ occurs in the condenser, whereas the maximum exergy loss of $42.73 \%$ occurs in the combustor. Verkhivker and Kosoy (2001) performed an exergy analysis on a power plant. A thermodynamic analysis of a subcritical boiler-turbine generator is carried out by Regulagadda et. al.(2010). They investigated the plant under various operating conditions, including different operating pressures, temperatures etc. In another study, Dinçer and Muslim (2001) performed a thermodynamic analysis of a reheat cycle power plant. Aljundi (2009) quantified the exergy loss in the components as well as the overall exergy loss of a thermal power plant and concluded that the maximum exergy destruction occurs in the boiler system by as much as $77 \%$ of the total exergy destruction of the power plant. Sengupta et. al. (2207) conducted an exergy analysis of a $210 \mathrm{MW}$ thermal power plant. Ozdemir et. al. (2010) performed an exergoeconomic analysis of fluidized bed coal combustor power plants.

The aim of this study is to design a thermal power plant and perform an exergy analysis based on the second law of thermodynamics to evaluate the exergetic efficiency and exergy destruction of the overall plant and each of its components, and to identify the extent and exact location of the exergy destruction in the system. The Sivas Kangal lignite is employed as a baseline. The effects of the ambient temperature on the exergy analysis are then investigated. Finally, the power plant is modeled assuming various types of Turkish lignite that are currently employed in real thermal power plants. The results are compared in terms of energy generation, exergetic efficiency and $\mathrm{CO}_{2}$ emissions for each type of lignite. 


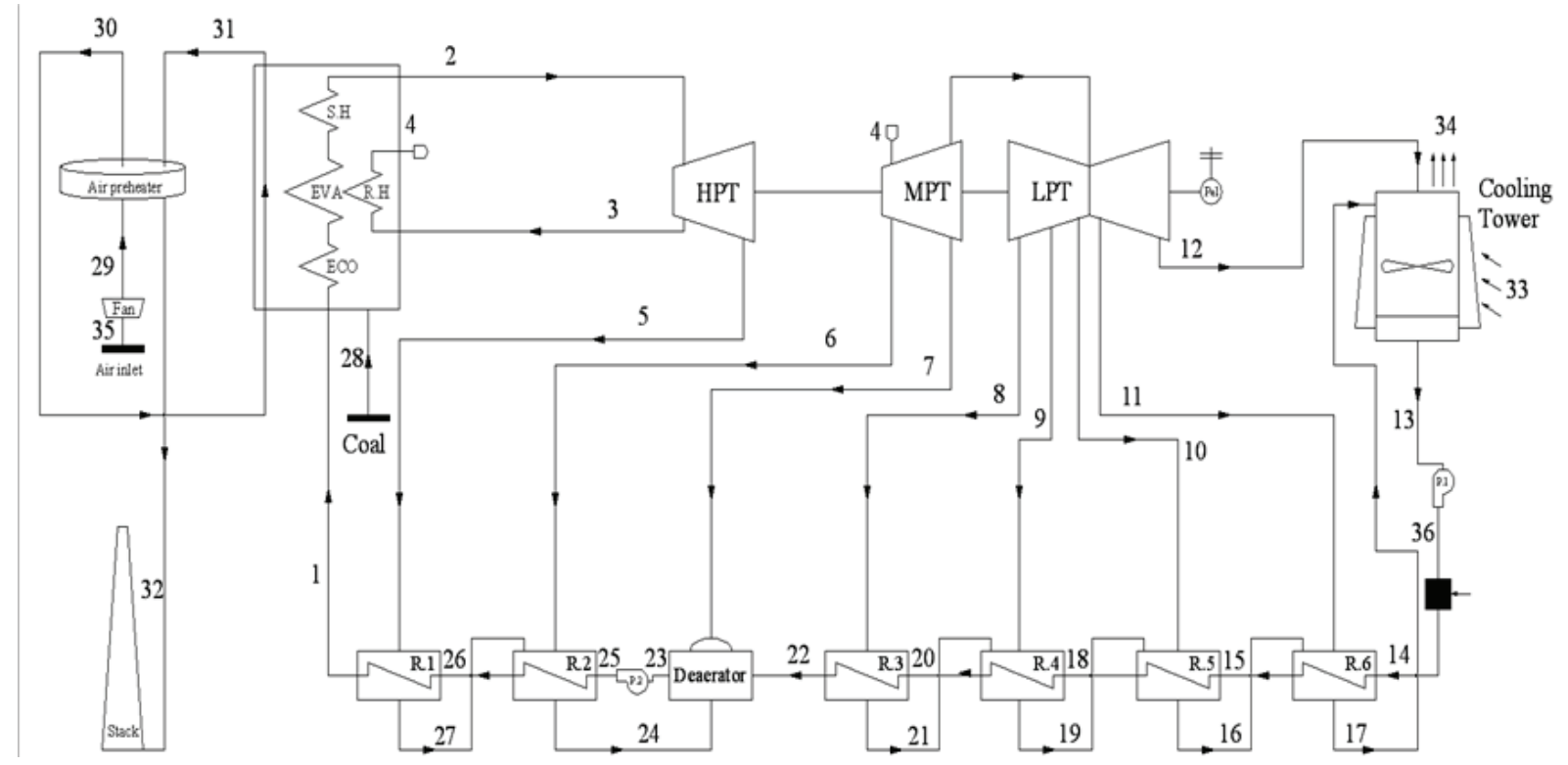

Figure 1. Schematic diagram of the power plant.

\section{Design of the Power Plant}

\subsection{General Description of Power Plant and Estimation of Boiler Capacity}

Figure 1 shows the schematic diagram of the power plant, demonstrating all of its relevant components. For the design of the power plant, the parameters which should be assumed as initial conditions are given in Table 1.

Table 1. Operating conditions of the power plant.

\begin{tabular}{ll}
\hline Operating condition & Value \\
\hline Turbine power output & $242.07 \mathrm{MW}$ \\
Main steam pressure & $205 \mathrm{bar}$ \\
Main steam temperature & $540{ }^{\circ} \mathrm{C}$ \\
Main steam flow rate & $203.8 \mathrm{~kg} / \mathrm{s}$ \\
Reheat steam pressure & $44.9 \mathrm{bar}$ \\
Reheat temperature & $540{ }^{\circ} \mathrm{C}$ \\
Reheat steam flow rate & $187.7 \mathrm{~kg} / \mathrm{s}$ \\
Condenser pressure & $0.075 \mathrm{bar}$ \\
Low pressure pre-heater number & 4 \\
High pressure pre-heater number & 2 \\
Boiler efficiency & $87 \%$ \\
\hline
\end{tabular}

After determination of the mentioned parameters of the thermal power plant (TPP), pressure and mass flow rate of bled steams, which can be achieved via optimization, are to be ascertained. By using Mollier diagram and thermodynamic tables for steam and thermodynamic equations, pressure, temperature, mass flow rate, enthalpy and entropy of each stream is obtained and given in Table 2.

To calculate the boiler capacity, the h-s diagram of the plant should be utilized, which is illustrated in Figure 2. Total heat transfer rate of each package included in the boiler gives the boiler capacity. For this purpose, the heat transfer rate of the each package is calculated by Eq. 1 . Here, $\dot{m}$ is the mass flow rate of water/steam and $\Delta \mathrm{h}$ is the enthalpy difference at the inlet and outlet of the each package.

$\dot{Q}_{i}[k W]=\dot{m} . \Delta h$

$\dot{Q}_{B}=\dot{Q}_{E V A}+\dot{Q}_{S . H .}+\dot{Q}_{R . H .}+\dot{Q}_{E C O}$

\subsection{Combustion Calculations}

Combustion is an exothermic high temperature oxidation process of combustible elements of a fuel with air. To obtain complete combustion, four major requirements must be fulfilled which are temperature, time, turbulence and sufficient oxygen. To calculate the combustion gas temperature at different points of the stream and overall plant emissions, air and gas flow rates must be evaluated. Specific oxygen requirement, which can be calculated with the elemental analysis of coal, is given in Eq. 3. Secondly, the specific air requirement is proportional to the volume percentage of $\mathrm{O}_{2}$ in the air and it is assumed as 0.21 for the calculations. To obtain complete combustion, excess air is provided to the combustion chamber and in the analysis excess air is assumed as $10 \%$ (Ozkan, 1983).

$O_{2 \min }\left[\frac{\mathrm{Nm}^{3}-\mathrm{O}_{2}}{\mathrm{~kg}-\mathrm{fuel}}\right]=1.87 \mathrm{C}+5.6(\mathrm{H}-\mathrm{O} / 8)+0.7 \mathrm{~S}$

$V_{a(t h)}\left[\frac{\mathrm{Nm}^{3}-a i r}{\mathrm{~kg}-\text { fuel }}\right]=(1 / 0.21) \cdot O_{2 \mathrm{~min}}$

$V_{a}\left[\frac{\mathrm{Nm}^{3}-\mathrm{O}_{2}}{\mathrm{~kg}-\mathrm{fuel}}\right]=n \cdot V_{a(t h)}$

The amount of the specific dry gas in theoretical combustion can be found by Eq. 6 . The theoretical volumes of combustion gas components can be obtained by the elemental analysis of coal, as indicated in Eqs. (7)-(10) (Ozkan, 1983). 
Table 2. Thermodynamic properties of each stream of the power plant.

\begin{tabular}{|c|c|c|c|c|c|c|}
\hline Point & State & $\mathrm{T}\left[{ }^{\circ} \mathrm{C}\right]$ & $\mathrm{P}[\mathrm{kPa}]$ & $\dot{m}[\mathrm{~kg} / \mathrm{s}]$ & $\mathrm{h}[\mathrm{kJ} / \mathrm{kg}]$ & $\mathrm{s}[\mathrm{kJ} / \mathrm{kg} \mathrm{K}]$ \\
\hline 1 & Water & 253.14 & 20537.00 & 205.80 & 1102.03 & 2.8220 \\
\hline 2 & Steam & 538.23 & 18929.00 & 203.80 & 3369.00 & 6.3269 \\
\hline 3 & Steam & 329.08 & 4712.00 & 187.70 & 3016.76 & 6.3878 \\
\hline 4 & Steam & 539.12 & 4284.00 & 187.70 & 3532.07 & 7.1655 \\
\hline 5 & Steam & 327.13 & 4523.00 & 16.09 & 3017.01 & 6.4046 \\
\hline 6 & Steam & 473.48 & 2603.50 & 8.65 & 3401.76 & 7.2257 \\
\hline 7 & Steam & 378.82 & 1337.20 & 9.41 & 3212.88 & 7.2557 \\
\hline 8 & Steam & 289.88 & 658.90 & 9.39 & 3038.84 & 7.2925 \\
\hline 9 & Steam & 192.23 & 267.60 & 8.94 & 2851.08 & 7.3387 \\
\hline 10 & Steam/Water & 96.70 & 90.04 & 8.48 & 2667.35 & 7.3809 \\
\hline 11 & Steam/Water & 62.22 & 22.08 & 4.78 & 2475.13 & 7.4559 \\
\hline 12 & Steam/Water & 40.32 & 7.50 & 138.10 & 2345.32 & 7.5226 \\
\hline 13 & Water & 40.32 & 7.50 & 169.60 & 168.75 & 0.5766 \\
\hline 14 & Water & 40.25 & 1510.50 & 171.70 & 169.80 & 0.5757 \\
\hline 15 & Water & 58.31 & 1469.20 & 171.70 & 245.26 & 0.8099 \\
\hline 16 & Water & 63.31 & 86.29 & 26.80 & 265.05 & 0.8726 \\
\hline 17 & Water & 45.25 & 21.16 & 31.58 & 189.39 & 0.6418 \\
\hline 18 & Water & 90.00 & 1427.80 & 171.70 & 378.06 & 1.1929 \\
\hline 19 & Water & 95.00 & 256.50 & 18.32 & 398.19 & 1.2504 \\
\hline 20 & Water & 122.00 & 1386.40 & 171.70 & 513.13 & 1.5493 \\
\hline 21 & Water & 127.00 & 631.50 & 9.39 & 533.86 & 1.6028 \\
\hline 22 & Water & 154.00 & 1345.00 & 171.70 & 650.17 & 1.8823 \\
\hline 23 & Water & 185.98 & 1345.00 & 205.80 & 789.87 & 2.1971 \\
\hline 24 & Water & 196.47 & 2495.00 & 24.74 & 837.32 & 2.2970 \\
\hline 25 & Water & 191.47 & 20620.00 & 205.80 & 823.55 & 2.2495 \\
\hline 26 & Water & 218.00 & 20579.00 & 205.80 & 940.73 & 2.4990 \\
\hline 27 & Water & 223.00 & 4335.00 & 16.09 & 958.56 & 2.5454 \\
\hline 28 & Fuel & 25.00 & 101.32 & 110.80 & 0.00 & 0.0000 \\
\hline 29 & Air & 26.55 & 102.82 & 325.40 & -160.87 & 6.9544 \\
\hline 30 & Air & 250.00 & 102.07 & 304.20 & 70.40 & 7.5321 \\
\hline 31 & Combustion gas & 326.17 & 102.07 & 397.20 & -4059.27 & 8.2628 \\
\hline 32 & Combustion gas & 179.37 & 101.32 & 418.50 & -4027.97 & 7.8957 \\
\hline 33 & Air & 25.00 & 101.32 & 4384.30 & -162.45 & 6.9534 \\
\hline 34 & Air & 34.60 & 101.32 & 4487.80 & -152.41 & 6.9857 \\
\hline 35 & Air & 25.00 & 101.32 & 325.40 & -162.45 & 6.9534 \\
\hline 36 & Water & 40.56 & 1510.50 & 169.60 & 171.08 & 0.5798 \\
\hline
\end{tabular}

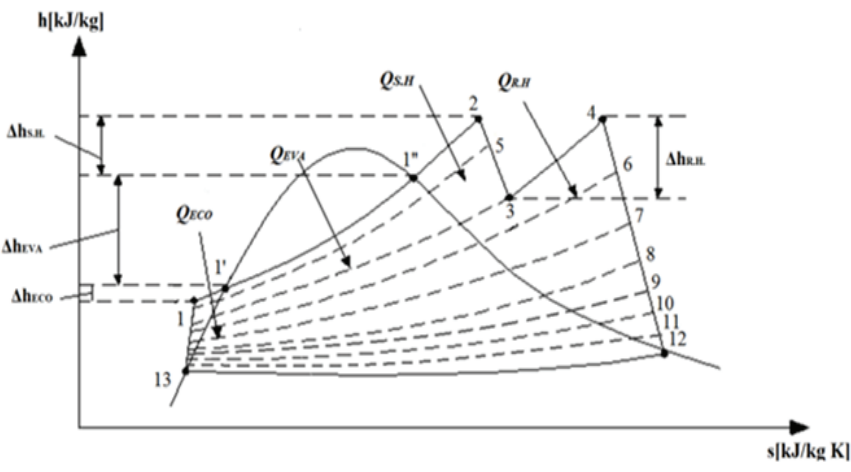

Figure 2. h-s diagram of the plant.

$V_{D G(\text { th })}\left[\frac{\mathrm{Nm}^{3}-\text { Gas }}{\mathrm{kg}-\text { fuel }}\right]=V_{\mathrm{CO} 2}+V_{\mathrm{SO} 2}+V_{N(\text { fuel })}+V_{N(\text { air })}$

$V_{\mathrm{CO} 2}\left[\frac{\mathrm{Nm}^{3}-\mathrm{CO}_{2}}{\mathrm{~kg}-\mathrm{fuel}}\right]=1.87 \mathrm{C}$

$V_{S O 2}\left[\frac{\mathrm{Nm}^{3}-\mathrm{SO}_{2}}{\mathrm{~kg}-\text { fuel }}\right]=0.7 \mathrm{~S}$
It should be noted that the combustible elements of the fuel are assumed to be combusted completely and nitrogen in the air and coal are not oxidized. Specific moisture content of the theoretical combustion gas can be calculated by combining Eqs. (6) and (1).

The volume of specific wet combustion gas with excess air can be found by using Eq. (13) (Ozkan, 1983).

$V_{\mathrm{H}_{2} \mathrm{O}}\left[\frac{\mathrm{Nm}^{3}-\mathrm{H}_{2} \mathrm{O}}{\mathrm{kg}-\text { fuel }}\right]=1.244(\mathrm{~W}+9 \mathrm{H})$

$V_{W G(t h)}\left[\frac{N m^{3}-G a s}{k g-f u e l}\right]=V_{D G(t h)}+V_{\mathrm{H}_{2} \mathrm{O}}$

$V_{W G}\left[\frac{N m^{3}-G a s}{k g-f u e l}\right]=V_{W G(t h)}+(n-1) V_{a(t h)}$ 
Total air requirement and volumetric flow rate of combustion gas are evaluated from Eqs. (14) and (15), these parameters affect the power consumption of the fans.

$\dot{V}_{a}\left[\frac{\mathrm{Nm}^{3}-a i r}{\mathrm{~kg}-\mathrm{fuel}}\right]=\dot{m}_{f u e l} . V_{a}$

$\dot{V}_{G}\left[\frac{N m^{3}-a i r}{k g-f u e l}\right]=\dot{m}_{f u e l} \cdot V_{W G}$

Mass flow rate of fuel consumed is evaluated by using Eq. (16), where $H u$ is the lower heating value of fuel obtained from elemental analysis of coal.

$$
\dot{m}_{\text {fuel }}=\frac{Q_{\text {boiler }}}{H u \eta_{\text {boiler }}}
$$

The combustion chamber temperature in the boiler can be calculated using the following equations.

$$
\begin{aligned}
& T_{C C}\left[{ }^{\circ} C\right]=\frac{\dot{m}_{\text {fuel }} \cdot L H V+\dot{V}_{a} \cdot C p_{\text {air }} \cdot T_{\text {air }}}{\dot{V}_{G} \cdot C p_{G}} \\
& T_{G(\mathrm{OUT})}\left[{ }^{\circ} C\right]=\frac{\dot{Q}_{i}}{\dot{V}_{G} \cdot C p_{G}}+T_{G(I N)}
\end{aligned}
$$

\subsection{Amount of Generated Power and Net Efficiency Assessment}

The power output of a TPP using water/steam as the working fluid is generated in a steam turbine. A steam turbine is a prime mover that continuously converts the energy of steam at high-pressure and high temperature into shaft work. As a result low temperature steam is exhausted to the condenser (Nag, 2008). Eq. (19) is useful for evaluating the power output of the steam turbine. It can be seen that, in this equation, mass flow rates of steam decreases due to the bled steam for preheating of feedwater.

$$
\begin{aligned}
& \dot{W}_{T}[M W]=\dot{m}_{2}\left(h_{2}-h_{5}\right)+\left(\dot{m}_{2}-\dot{m}_{5}\right)\left(h_{5}-h_{6}\right) \\
& \quad+\left(\dot{m}_{2}-\dot{m}_{5}-\dot{m}_{6}\right)\left(h_{6}-h_{7}\right) \\
& \quad+\left(\dot{m}_{2}-\dot{m}_{5}-\dot{m}_{6}-\dot{m}_{7}\right)\left(h_{7}-h_{8}\right) \\
& \quad+\left(\dot{m}_{2}-\dot{m}_{5}-\dot{m}_{6}-\dot{m}_{7}-\dot{m}_{8}\right)\left(h_{8}-h_{9}\right) \\
& \quad+\left(\dot{m}_{2}-\dot{m}_{5}-\dot{m}_{6}-\dot{m}_{7}-\dot{m}_{8}-\dot{m}_{9}\right)\left(h_{9}-h_{10}\right) \\
& \quad+\left(\dot{m}_{2}-\dot{m}_{5}-\dot{m}_{6}-\dot{m}_{7}-\dot{m}_{8}-\dot{m}_{9}-\dot{m}_{10}\right)\left(h_{10}-h_{11}\right) \\
& \quad+\left(\dot{m}_{2}-\dot{m}_{5}-\dot{m}_{6}-\dot{m}_{7}-\dot{m}_{8}-\dot{m}_{9}-\dot{m}_{10}-\dot{m}_{11}\right)\left(h_{11}-h_{12}\right) \\
& \dot{W}_{n e t}[M W]=\dot{W}_{T}-\sum \dot{W}_{\text {aux }}
\end{aligned}
$$

The net electrical efficiency of a power plant is defined as follows:

$$
\begin{aligned}
& \eta_{\text {net }}=\eta_{\mathrm{I}} \\
& =\frac{\text { net generated power by power plant }}{\text { rate of energy released in boiler by the combustion of fuel }} \\
& =\frac{P_{e l}}{\dot{m}_{\text {fuel }} L H V}
\end{aligned}
$$

\section{Exergy Analysis}

The exergy of a system is defined as the maximum available work that can be done by the system-environment combination. Higher values of exergy means a higher value of obtainable work. The exergy analysis is the composite of the first and second laws of thermodynamics. In this analysis heat does not have the same value as work, and exergy loss represents a real loss of work. When analyzing novel and complex thermal systems, experience needs to be supplemented by more rigorous quantitative analytical tools. Exergy analysis provides those tools and it helps in locating weak spots in a process. This analysis provides a quantitative measure of the quality of the energy in terms of its ability to perform work and leads to a more rational use of energy (Oktay, 2009).

Conservation of mass, conservation of energy and exergy destruction equations for any control volume at steady state with negligible kinetic and potential energy changes can be written as in Eqs. (21)-(23). By neglecting the potential and kinetic exergy changes of the system, Eq. (24) defines the total exergy rate. In Eq. (24), the subscript " 0 " indicates the reference conditions, which are, in this study, ambient temperature as $25^{\circ} \mathrm{C}$ and atmospheric pressure as $101.32 \mathrm{kPa}$, respectively.

$$
\begin{aligned}
& \sum_{i} \dot{m}_{i}=\sum_{e} \dot{m}_{e} \\
& \dot{Q}_{j}-\left(\dot{W}_{c v}\right)=\sum_{e} \dot{m}_{e} h_{e}-\sum_{i} \dot{m}_{i} h_{i} \\
& \dot{E}_{D}=\sum_{j}\left(1-\frac{T_{0}}{T_{i}}\right) \dot{Q}_{j}-\left(\dot{W}_{c v}\right)+\sum_{i} \dot{E}_{i}-\sum_{e} \dot{E}_{e} \\
& \dot{E}=\dot{m}\left[h-h_{0}-T_{0}\left(s-s_{0}\right)+\bar{e}_{C H}\right]
\end{aligned}
$$

Furthermore, the chemical exergy of a substance $\left(\bar{e}_{C H}\right)$ can be obtained from standard chemical exergy tables (Bejan et. al., 1996; Kotas, 1985) with the specification of the environment. For mixtures containing gases other than those in the reference tables, chemical exergy can be evaluated by using the following equation.

$$
\bar{e}_{C H}=\sum x_{n}\left(\bar{e}_{C H}\right)_{n}+\bar{R} T_{0} \sum x_{n} \ln x_{n}
$$

Here, $x_{n}$ is the mol fraction of the $\mathrm{k}^{\text {th }}$ gas in the mixture and $\bar{R}$ is the universal gas constant.

$$
\bar{e}_{C H(f u e l)}=\beta .(L H V)
$$

In Eq. 27, $\bar{e}_{C H(f u e l)}$ is the fuel specific exergy, and the exergy factor based on the lower heating value $(\beta)$ is given by [11],

$$
\beta=1.0437+0.1882\left(\frac{h}{c}\right)+0.0610\left(\frac{o}{c}\right)+0.0404\left(\frac{n}{c}\right)
$$

Considering each component in Figure 1 as a control volume, the exergy equations can be derived from the general exergy equation (Eq. 23). It should be noted that exergy destruction caused by the heat loss from the components are ignored in this study, since it is assumed 
that the boundary temperature $\left(T_{j}\right)$ of the each component is equal to the dead state temperature $\left(T_{0}\right)$.

Another parameter in an exergy analysis of a system is determining the exergetic efficiency, which is the percentage of the fuel exergy provided to a system over the exergy of the product. Moreover, the difference between $100 \%$ and the actual value of the exergy efficiency, expressed as a percent, is the percentage of the fuel exergy wasted in this system as exergy destruction and exergy loss (Bejan et. al., 1996).

$$
\eta_{\text {II }}=\frac{\dot{E}_{P}}{\dot{E}_{F}}
$$

Generally, the exergy of the product emphasizes the desired outcome of the system, whilst the exergy of the fuel represents the entire resources given to the system. Considering this fact, for different components of the power plant, the desired outcome and the given resource are not the same. Further expressions and efficiencies of exergy for each component are given in Appendix 1.

\section{Results}

\subsection{Energy and Exergy Results of the TPP Operated with Kangal Lignite}

The parametric design of power plant is made with the equations given previously and the data given in Tables 1 and 2 , and the results are summarized in Table 3.

Table 3. Thermal power plant summary.

\begin{tabular}{ll}
\hline Total generated power & $257.73 \mathrm{MW}$ \\
\hline Total plant auxiliary & $15.65 \mathrm{MW}$ \\
Total fuel consumption & $110.8 \mathrm{~kg} / \mathrm{s}$ \\
Net power & $242.10 \mathrm{MW}$ \\
Net energy efficiency & 37.16 \\
Plant total CO2 emissions & $2,333,445 \mathrm{ton} /$ year \\
\hline
\end{tabular}

The exergy analysis of a power plant is fulfilled with the equations given in previous pages. The physical, chemical and total exergy rates of air, combustion gases, fuel, steam and water at various points were computed and summarized in Table 4.

It is assumed that the chemical exergy of the air at points 29, 30, 33, 34 and 35 is zero, since the air composition at these points resembles the air composition of the reference environment.

Table 5 provides a list of the exergy destruction and exergetic efficiency data for various components of the plant. It can be seen that the maximum exergy destruction occurs in the boiler with a value of $83.29 \%$ of the total exergy destruction. It seems obvious from the data in Table 5 that the irreversibility associated with chemical reactions is the main source of exergy destruction. The other prominent components in exergy destruction are the steam turbine and air pre-heater with 6.15 and $3.99 \%$, respectively, of total exergy destruction.

In contrast to the first law analysis indicating that the greatest energy loss occurs from the condenser, the exergy analysis of this plant shows that only $3.27 \%$ of the total exergy is lost from the condenser. The total exergy destruction of the plant is calculated to be $359.10 \mathrm{MW}$.
Table 4. Physical, chemical and total exergy values of each stream.

\begin{tabular}{|c|c|c|c|c|}
\hline Point & State & $\begin{array}{l}\mathrm{E}^{\mathrm{PH}} \\
{[\mathrm{MW}]}\end{array}$ & $\mathrm{E}^{\mathrm{CH}} \quad[\mathrm{MW}]$ & $\begin{array}{l}\mathrm{E}_{\text {total }} \\
{[\mathrm{MW}]}\end{array}$ \\
\hline 1 & Water & 54.60 & 0.51 & 55.12 \\
\hline 2 & Steam & 303.11 & 0.51 & 303.62 \\
\hline 3 & Steam & 209.64 & 0.47 & 210.11 \\
\hline 4 & Steam & 262.84 & 0.47 & 263.31 \\
\hline 5 & Steam & 17.89 & 0.04 & 17.93 \\
\hline 6 & Steam & 10.83 & 0.02 & 10.85 \\
\hline 7 & Steam & 9.92 & 0.02 & 9.95 \\
\hline 8 & steam & 8.16 & 0.02 & 8.18 \\
\hline 9 & Steam & 5.97 & 0.02 & 5.99 \\
\hline 10 & Steam/Water & 4.00 & 0.02 & 4.02 \\
\hline 11 & Steam/Water & 1.23 & 0.01 & 1.24 \\
\hline 12 & Steam/Water & 14.79 & 0.34 & 15.14 \\
\hline 13 & Water & 0.25 & 0.42 & 0.68 \\
\hline 14 & Water & 0.48 & 0.43 & 0.91 \\
\hline 15 & Water & 1.45 & 0.43 & 1.88 \\
\hline 16 & Water & 0.26 & 0.07 & 0.32 \\
\hline 17 & Water & 0.09 & 0.05 & 0.13 \\
\hline 18 & Water & 4.65 & 0.43 & 5.07 \\
\hline 19 & Water & 0.55 & 0.05 & 0.60 \\
\hline 20 & Water & 9.59 & 0.43 & 10.02 \\
\hline 21 & Water & 0.57 & 0.02 & 0.59 \\
\hline 22 & Water & 16.08 & 0.43 & 16.50 \\
\hline 23 & Water & 28.70 & 0.51 & 29.22 \\
\hline 24 & Water & 3.89 & 0.06 & 3.95 \\
\hline 25 & Water & 32.42 & 0.51 & 32.93 \\
\hline 26 & Water & 41.22 & 0.51 & 41.74 \\
\hline 27 & Water & 3.29 & 0.04 & 3.33 \\
\hline 28 & Fuel & 0.00 & 694.73 & 694.73 \\
\hline 29 & Air & 0.42 & 0.00 & 0.42 \\
\hline 30 & Air & 18.34 & 0.00 & 18.34 \\
\hline 31 & $\begin{array}{l}\text { Combustion } \\
\text { gas }\end{array}$ & 46.00 & 69.98 & 115.98 \\
\hline 32 & $\begin{array}{l}\text { Combustion } \\
\text { gas }\end{array}$ & 14.92 & 68.80 & 83.72 \\
\hline 33 & Air & 0.00 & 0.00 & 0.00 \\
\hline 34 & Air & 3.89 & 0.00 & 3.89 \\
\hline 35 & Air & 0.00 & 0.00 & 0.00 \\
\hline 36 & Water & 0.49 & 0.42 & 0.91 \\
\hline
\end{tabular}

Dead state condition: $T_{0}=25^{\circ} \mathrm{C}$ and $P_{0}=101.32 \mathrm{kPa}$.

From Table 5 it is observed that the deaerator, steam turbine, and pre-heater No.1 have the maximum exergetic efficiencies of $96.11,92.21$, and $91.58 \%$, and that the condenser, boiler and pumps have the minimum exergetic efficiencies of $27.98,50.22,50.57$ and $54.91 \%$. The overall plant exergetic efficiency is $35.49 \%$. Compared to the net first law efficiency of the plant of $37.16 \%$, it can be seen that the exergetic efficiency is less than the energetic efficiency, as indicated in the previous section. According to the results of the exergy analysis, the boiler, steam turbine, air pre-heater and condenser should be designed to decrease exergy destruction percentages.

Figure 3 depicts clearly the effects of ambient air temperatures (between -10 and $35{ }^{\circ} \mathrm{C}$ ) on exergetic efficiency and also on $\mathrm{CO}_{2}$ emissions of the power plant. For instance, a $45^{\circ} \mathrm{C}$ increase in the ambient temperature results in a decrease in the second law efficiency of the overall plant from $35.25 \%$ to $34.54 \%$. On the other hand, with increasing ambient temperature, $\mathrm{CO}_{2}$ emissions increase from 2,297,396 to 2,343,953 ton/year, which has serious results on the natural environment, as is well known.

\subsection{General Results of Other TPP's}

Figure 4 is a comparative summary of the exergy destruction, exergetic efficiency and generated power between the different TPP's operating with different types of Turkish lignite, whose characteristics are given in Table 6. From the same Figure, generated power of all plants are 
Table 5. Exergy destruction data and exergy efficiency of the Kangal power plant components.

\begin{tabular}{llll}
\hline Components & $\begin{array}{l}\text { Exergy } \\
\text { destruction } \\
{[\mathrm{MW}]}\end{array}$ & $\begin{array}{l}\text { Percent exergy } \\
\text { destruction[\%] }\end{array}$ & $\begin{array}{l}\text { Percent } \\
\text { exergy } \\
\text { efficiency[\%] }\end{array}$ \\
\hline Air fan & 0.13 & 0.04 & 76.27 \\
Air pre-heater & 14.34 & 3.99 & 55.57 \\
Boiler & 299.10 & 83.29 & 50.22 \\
Steam turbine & 22.10 & 6.15 & 92.21 \\
Condenser & 11.75 & 3.27 & 27.98 \\
FWH 6 & 0.47 & 0.13 & 67.53 \\
FWH 5 & 1.10 & 0.30 & 74.48 \\
FWH 4 & 1.04 & 0.29 & 82.65 \\
FWH 3 & 1.11 & 0.31 & 85.41 \\
Deaerator & 1.18 & 0.33 & 96.11 \\
FWH 2 & 1.42 & 0.40 & 86.12 \\
FWH 1 & 1.23 & 0.34 & 91.58 \\
Condense & 0.66 & 0.18 & 54.91 \\
Pump (P1) & & 1.01 & 50.57 \\
Circulation & 3.63 & 100.00 & 34.84 \\
Pump (P2) & 359.10 & & \\
Overall plant & 35 & \\
\hline
\end{tabular}

approximately equal, since the properties of the inlet and outlet steams of the turbines are of the same value, directly affecting the output power of the power plants.

Additionally the maximum exergy destruction occurs in the Seyitömer plant with 389.37 MW. Soma and Elbistan plants show 386.98 and $383.32 \mathrm{MW}$ subsequently. On the contrary, the minimum exergy destruction occurs in Kangal and Çan plants with 360.23 and 361.59 MW efficiencies. Moreover, it can be determined from Figure 4 that the highest and lowest second law efficiencies among the other lignites exist at Yeniköy and Elbistan plants respectively.

For a deeper insight into the conclusions, a summary of $\mathrm{CO}_{2}$ emissions and feeding fuel rate of the thermal power plants are presented in Figure 5. It is obvious that Kangal and Elbistan plants have the maximum fuel consumptions of 110.8 and $101.86 \mathrm{~kg} / \mathrm{s}$. Additionally, they have also maximum $\mathrm{CO}_{2}$ emissions as well. To be noted, Tunçbilek, Yeniköy and Orhaneli plants have very low values of $\mathrm{CO}_{2}$ emissions, respectively 42.50, 42.69, and $39.01 \mathrm{~kg} / \mathrm{s}$.

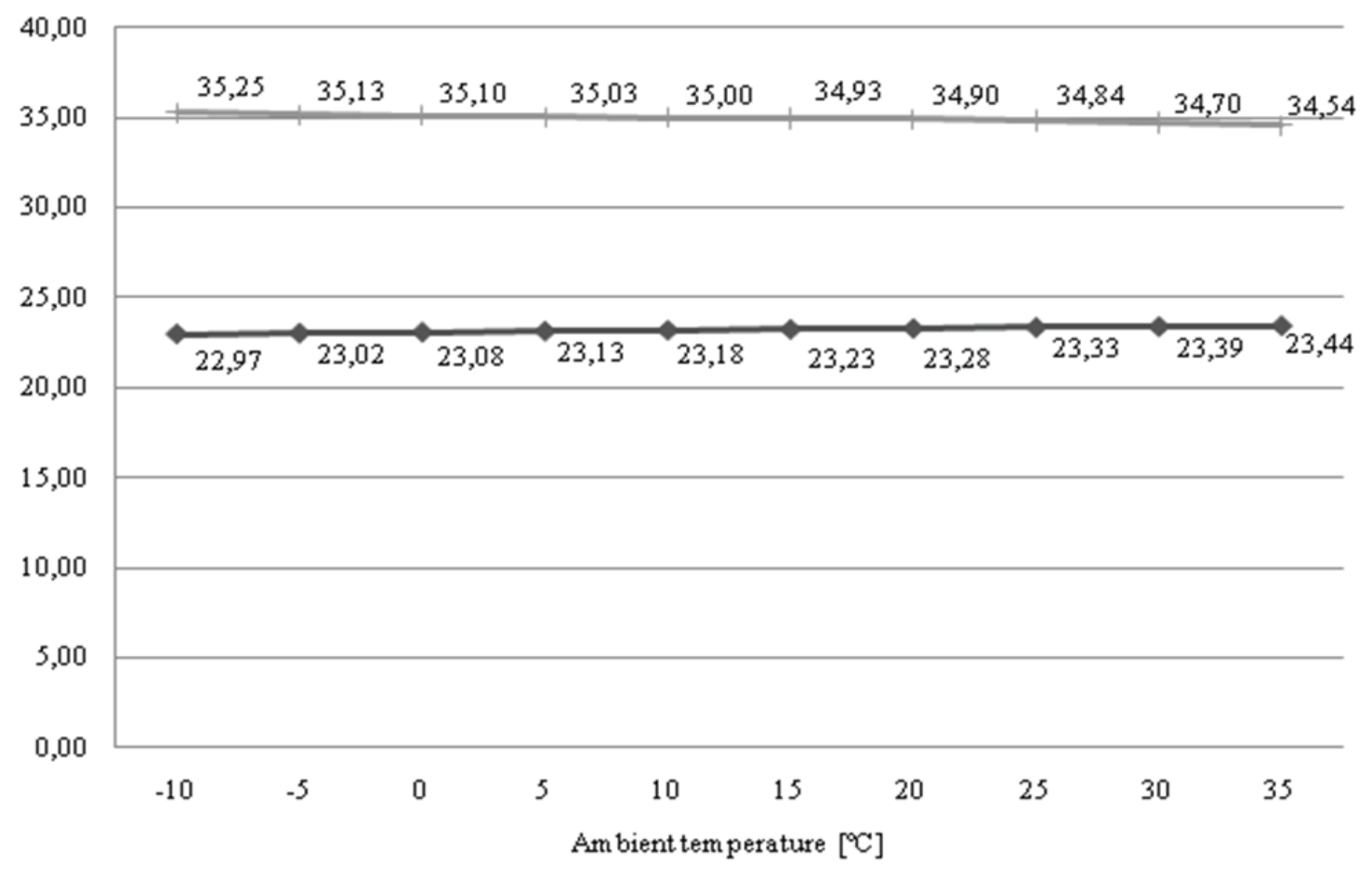

$\longrightarrow$ ex ergy efficiency [\%] —CO2 Emissions [tonne/year*10^5]

Figure 3. Effect of ambient temperature on exergy efficiency and $\mathrm{CO}_{2}$ emission.

Table 6. Elemental analysis and lower heating values of the Turkish lignites.

\begin{tabular}{lllllllll}
\hline Lignite & $\mathrm{C}[\%]$ & $\mathrm{H}[\%]$ & $\mathrm{O}[\%]$ & $\mathrm{S}[\%]$ & $\mathrm{N}[\%]$ & $\mathrm{W}[\%]$ & $\mathrm{A}[\%]$ & $\mathrm{LHV}[\mathrm{kJ} / \mathrm{kg}]$ \\
\hline Kangal & 19.70 & 1.55 & 8.81 & 1.29 & 0.58 & 52.00 & 16.07 & 5876.3 \\
Çayırhan & 31.68 & 2.58 & 7.81 & 2.49 & 1.23 & 24.69 & 29.52 & 11156.42 \\
Elbistan & 21.19 & 1.83 & 9.4 & 0.81 & 0.52 & 49.33 & 16.92 & 6395.4 \\
Orhaneli & 47.46 & 3.29 & 11.97 & 1.56 & 2.00 & 26.25 & 7.47 & 16084.64 \\
Seyitömer & 20.81 & 1.78 & 9.35 & 0.31 & 1.15 & 38.12 & 28.48 & 6797 \\
Tunçbilek & 42.52 & 2.84 & 12.68 & 1.98 & 0.98 & 27.38 & 11.62 & 14734 \\
Yatağan & 29.16 & 2.55 & 12.68 & 1.85 & 0.27 & 31.17 & 22.32 & 10253.54 \\
Soma & 38.64 & 2.74 & 16.40 & 0.01 & 0.59 & 18.64 & 22.98 & 13455.42 \\
Yeniköy & 39.05 & 3.02 & 11.21 & 1.42 & 1.46 & 24.26 & 19.58 & 14625.82 \\
Çan & 30.18 & 2.45 & 10.06 & 5.28 & 0.31 & 20.36 & 31.36 & 10604.66 \\
\hline Data aretaken
\end{tabular}

Data are taken from MTA 2002 (as received mass basis). 


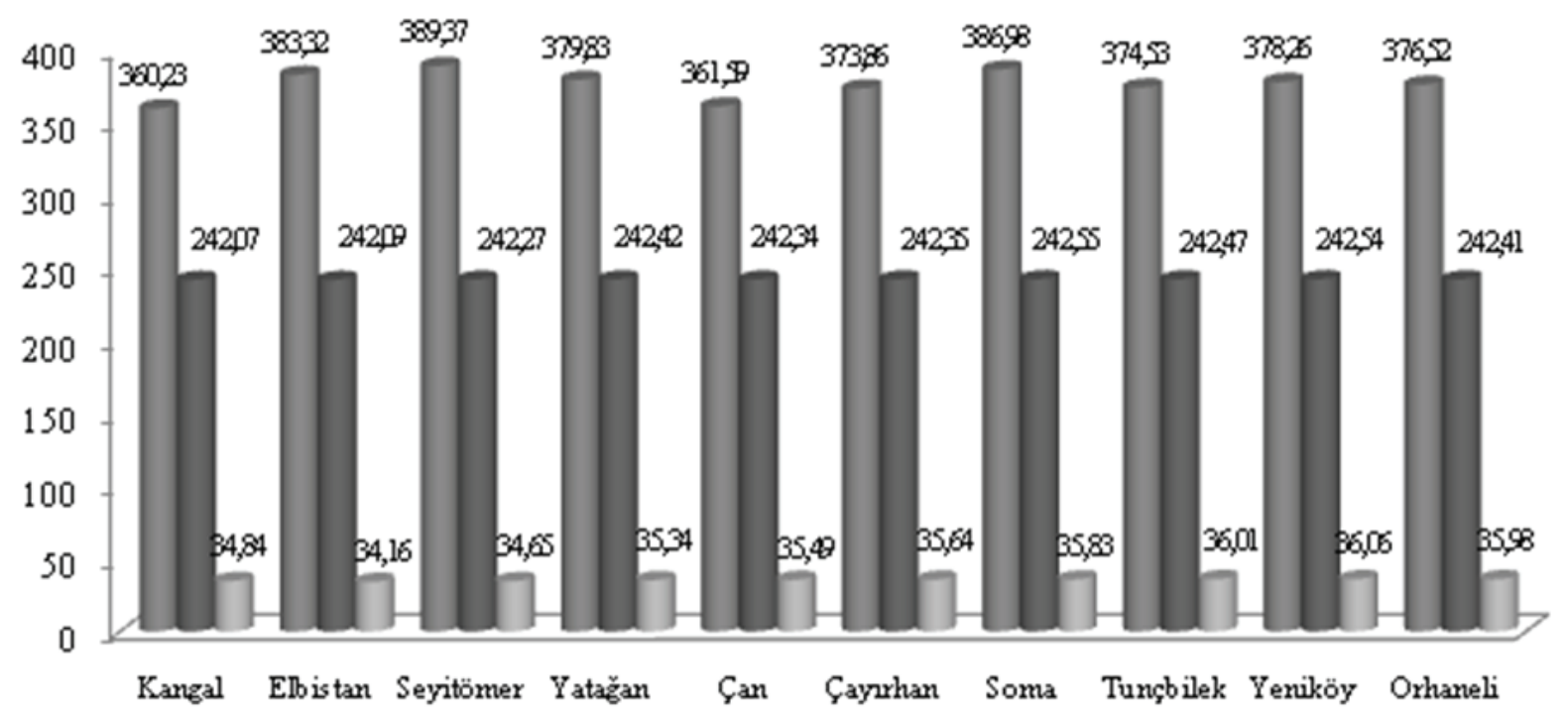

\section{$\|$ Exergy Destruction [MW] $\quad$ Net Power [MW] $\quad$ Exergy efficiency [\%]}

Figure 4. Exergy destruction rate, exergy efficiency, and generated net power of the different power plants.

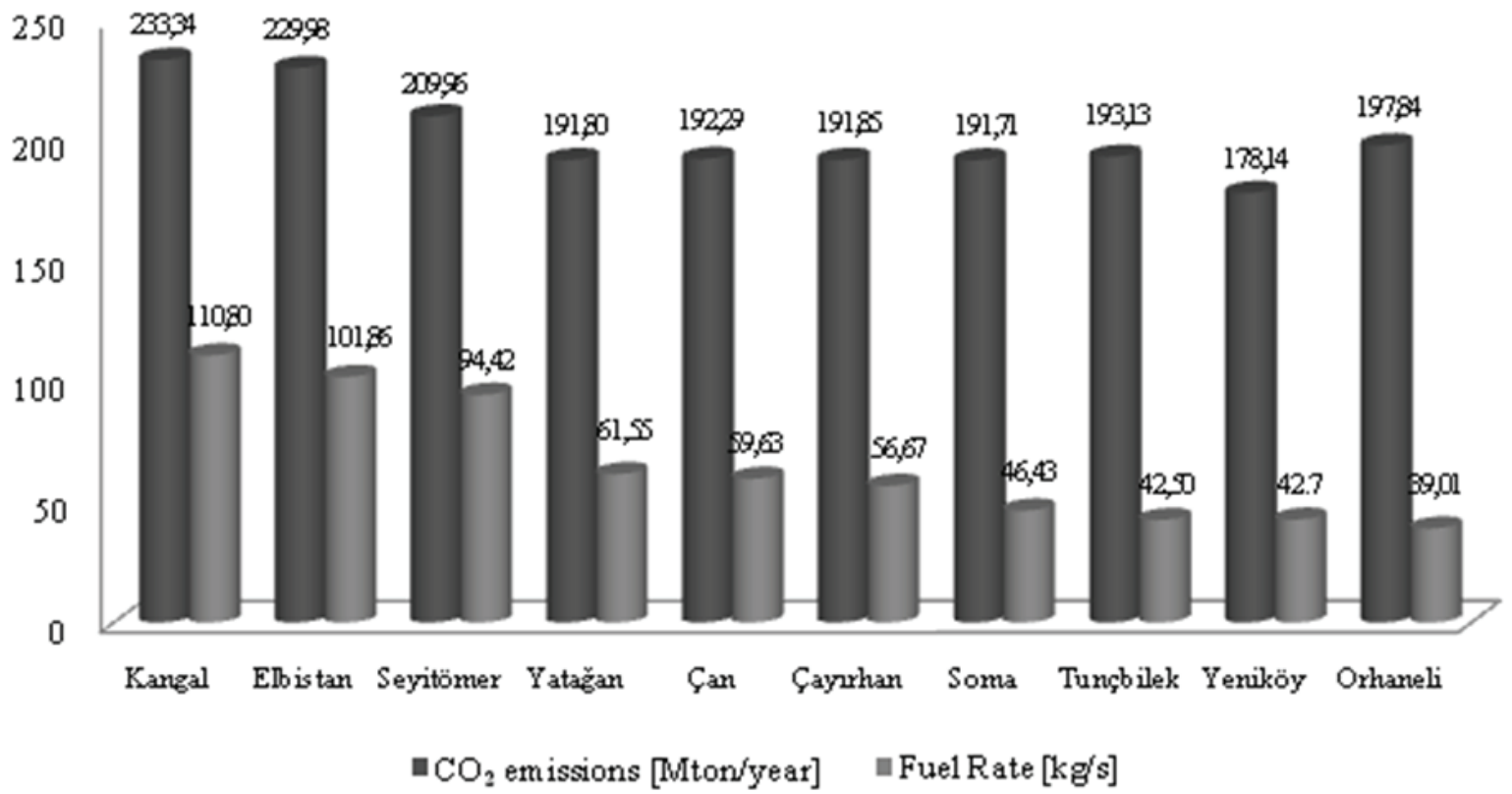

Figure 5. $\mathrm{CO}_{2}$ emissions and fuel rates of the different power plants.

\section{Conclusions}

In this study, initially a thermal power plant is designed and then an exergy analysis is performed for this plant. The exergy destruction rates and exergy efficiencies of each component of the plant are evaluated. The analysis includes 9 different lignite types. Also fuel rates and $\mathrm{CO}_{2}$ emission values of each case are determined and compared.

Several important results drawn from this study are summarized below:

- Total generated power of the Sivas Kangal lignite considered in this study is found to be $242.07 \mathrm{MW}$ and its net energy efficiency is $37.16 \%$. Total exergy destruction and the net exergetic efficiency of the plant is $359.10 \mathrm{MW}$ and $34.84 \%$ respectively. Exergy analysis shows that the main exergy destruction takes place in the boiler as 299.10 MW and with an $83.29 \%$ exergetic efficiency. Increasing ambient temperature causes an increase in fuel consumption and consequently diminishes the exergetic efficiency. $\mathrm{CO}_{2}$ emission increase is another result of the increase in ambient temperature.

- From exergetic efficiency and $\mathrm{CO}_{2}$ emissions, it can be stated that, Yeniköy lignite is the best type among those considred for the same power generation capacity.

- The maximum exergy destruction occured in the Seyitömer lignite case. The main reason of this can be seen from the elemental analysis of lignites. Carbon and hydrogen percentages of this type are the lowest among the other types of lignites. 


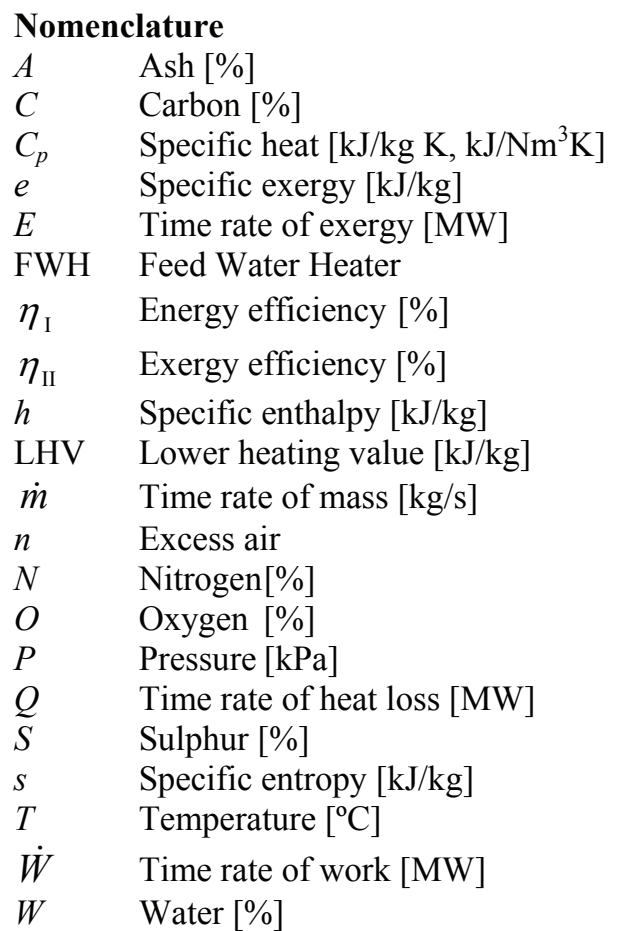

\section{Subscripts}

$\begin{array}{ll}a & \text { Air } \\ B & \text { Boiler } \\ C H & \text { Chemical } \\ C V & \text { Control volume } \\ D & \text { Destruction } \\ D G & \text { Dry gas } \\ E C O & \text { Economizer } \\ E V A & \text { Evaporator } \\ G & \text { Combustion gas } \\ i & \text { Inlet } \\ K N & \text { Kinetic } \\ o & \text { Outlet } \\ P & \text { Product } \\ P H & \text { Physical } \\ P T & \text { Potential } \\ R . H & \text { Re-heater } \\ S . H & \text { Super-heater } \\ S T & \text { Steam turbine } \\ t h & \text { Theoretic } \\ W G & \text { Wet gas }\end{array}$

\section{References:}

Aljundi I. H. (2009). Energy and exergy analysis of a steam power plant in Jordan. Applied Thermal Engineering 29, 324-328.

Bejan A., Tsatsaronis G., Moran M., (1996). Thermal Design and Optimization, By Jhon Wiley \& Sons, Inc.

Dincer I., Muslim H.A., (2001). Thermodynamic analysis of reheats cycle steam power plants. International Journal of Energy Research 25, 727-739.

Erdem H. H., Akkaya A. V., Cetin B., Dagdas A., Sevilgen S. H., Sahin B., Teke I., Gungor C., Atas S., (2009). Comparative energetic and exergetic performance analyses for coal-fired thermal power plants in Turkey. International Journal of Thermal Sciences, 48, 21792186

Ganapathy T., Alagumurthi N., Gakkhar R. P. and Murugesan, (2009). Exergy Analysis of Operating Lignite Fired Thermal Power. Journal of Engineering Science and Technology Review 2 (1), 123-130.

Kopac M., Hilalci A., (2007). Effect of ambient temperature on the efficiency of the regenerative and reheat Catalagzi power plant in Turkey. Applied Thermal Engineering 27, 1377-1385.

Kotas T. J., (1985). The Exergy Method of Thermal Plant Analysis, by Anchor Brendon Ltd, Tiptree, Essex.

Nag P.K., (2008). Power Plant Engineering, by Tata McGraw-Hill Publishing Company Limited, 7 West Patel Nagar, New Delhi 110008.

Oktay Z., (2009). Investigation of coal-fired power plants in Turkey and a case study: Can plant. Applied Thermal Engineering 29, 550-557.

Ozkan M., (1983). Steam Boilers Thermal Calculations, Gazi University Press, Ankara.

Ozdemir K., Hepbasli A., Eskin N., (2010). Exergoeconomic analysis of a fluidized bed coal combustor (FBCC) steam power plant, Applied Thermal Engineering, doi:

$10.1016 /$ j.applthermaleng.2010.03.020.

Regulagadda P., Dincer I., Naterer G. F., (2010). Exergy analysis of a thermal power plant with measured boiler and turbine losses. Applied Thermal Engineering 30, 970-976.

Sengupta S., Datta A., Duttagupta S., (2007). Exergy analysis of a coal-based $210 \mathrm{MW}$ thermal power plant, International Journal of Energy Research 31, 14-28.

Tuncali E., Ciftci B., Yavuz N., Toprak S., Koker A., Aycik H., Gencer Z., Sahin N., (2002). Chemical and Technological Properties of Turkish Tertiary Coals, General Directorate of Mineral Research and Exploration (MTA) ANKARA.

Verkhivker G. P., Kosoy B. V., (2001). on the exergy analysis of power plants, Energy conversion and management 42, 2053-2059.

\section{Appendix 1.}

The Exergy formulas and efficiencies of each component are given in the Table Appendix 1. 


\begin{tabular}{|c|c|c|c|c|c|}
\hline Components & $\sum \dot{E}_{i n}$ & $\sum \dot{E}_{\text {out }}$ & $\dot{W}$ & $\dot{E}_{D}$ & $\eta_{\mathrm{II}}=\frac{\dot{E}_{P}}{\dot{E}_{F}}$ \\
\hline Air fan & $\dot{E}_{35}$ & $\dot{E}_{29}$ & $\dot{W}_{f a n}$ & $\begin{array}{l}-\left(-\dot{W}_{f a n}\right) \\
+\dot{E}_{35}-\dot{E}_{29}\end{array}$ & $\frac{\dot{E}_{35}-\dot{E}_{29}}{\dot{W}_{f a n}}$ \\
\hline $\begin{array}{c}\text { Air } \\
\text { pre-heater }\end{array}$ & $\dot{E}_{29}+\dot{E}_{31}$ & $\dot{E}_{30}+\dot{E}_{32}$ & - & $\begin{array}{l}\dot{E}_{29}+\dot{E}_{31} \\
-\dot{E}_{30}-\dot{E}_{32}\end{array}$ & $\frac{\dot{E}_{30}-\dot{E}_{29}}{\dot{E}_{31}-\dot{E}_{32}}$ \\
\hline Boiler & $\begin{array}{l}\dot{E}_{1}+\dot{E}_{3} \\
+\dot{E}_{28}+\dot{E}_{30}\end{array}$ & $\dot{E}_{2}+\dot{E}_{4}+\dot{E}_{31}$ & $\dot{W}_{f p}$ & $\begin{array}{l}-\left(-\dot{W}_{f p}\right)+\dot{E}_{1} \\
+\dot{E}_{3}+\dot{E}_{28}+\dot{E}_{30} \\
-\dot{E}_{2}-\dot{E}_{4}-\dot{E}_{31}\end{array}$ & $\frac{\left(\dot{E}_{2}-\dot{E}_{1}\right)+\left(\dot{E}_{4}-\dot{E}_{3}\right)}{\dot{E}_{28}+\dot{E}_{30}+\dot{E}_{31}+\dot{W}_{f p}}$ \\
\hline $\begin{array}{l}\text { Steam } \\
\text { turbine }\end{array}$ & $\dot{E}_{2}+\dot{E}_{4}$ & $\begin{array}{l}\dot{E}_{3}+\dot{E}_{5} \\
+\dot{E}_{6}+\dot{E}_{7} \\
+\dot{E}_{8}+\dot{E}_{9} \\
+\dot{E}_{10}+\dot{E}_{11} \\
+\dot{E}_{12}\end{array}$ & $\dot{W}_{S T}$ & $\begin{array}{l}-\left(\dot{W}_{S T}\right)+\dot{E}_{2}+\dot{E}_{4} \\
-\dot{E}_{3}-\dot{E}_{5}-\dot{E}_{6} \\
-\dot{E}_{7}-\dot{E}_{8}-\dot{E}_{9} \\
-\dot{E}_{10}-E_{11}-\dot{E}\end{array}$ & $\frac{\dot{W}_{G T}}{\left(\dot{E}_{2}-\dot{E}_{5}-\dot{E}_{6}-\dot{E}_{7}-\dot{E}_{8}-\dot{E}_{9}-\dot{E}_{10}-E_{11}-\dot{E}_{12}\right)+\left(\dot{E}_{4}-\dot{E}_{3}\right)}$ \\
\hline Condenser & $\begin{array}{l}\dot{E}_{12}+\dot{E}_{17} \\
+\dot{E}_{33}\end{array}$ & $\dot{E}_{13}+\dot{E}_{34}$ & $\dot{W}_{c t}$ & $\begin{array}{l}-\left(-\dot{W}_{c t}\right)+\dot{E}_{12} \\
+\dot{E}_{17}+\dot{E}_{33} \\
-\dot{E}_{13}-\dot{E}_{34}\end{array}$ & $\frac{\dot{E}_{13}+\dot{E}_{34}}{\dot{E}_{12}+\dot{E}_{17}+\dot{E}_{33}+\dot{W}_{c t}}$ \\
\hline FWH 6 & $\begin{array}{l}\dot{E}_{11}+\dot{E}_{14} \\
+\dot{E}_{16}\end{array}$ & $\dot{E}_{15}+\dot{E}_{17}$ & - & $\begin{array}{l}\dot{E}_{11}+\dot{E}_{14}+\dot{E}_{16} \\
-\dot{E}_{15}-\dot{E}_{17}\end{array}$ & $\frac{\dot{E}_{15}-\dot{E}_{14}}{\dot{E}_{11}+\dot{E}_{16}-\dot{E}_{17}}$ \\
\hline FWH 5 & $\begin{array}{l}\dot{E}_{10}+\dot{E}_{15} \\
+\dot{E}_{19}\end{array}$ & $\dot{E}_{16}+\dot{E}_{18}$ & - & $\begin{array}{l}\dot{E}_{10}+\dot{E}_{15}+\dot{E}_{19} \\
-\dot{E}_{16}-\dot{E}_{18}\end{array}$ & $\frac{\dot{E}_{18}-\dot{E}_{15}}{\dot{E}_{10}+\dot{E}_{19}-\dot{E}_{16}}$ \\
\hline FWH 4 & $\begin{array}{l}\dot{E}_{9}+\dot{E}_{18} \\
+\dot{E}_{21}\end{array}$ & $\dot{E}_{19}+\dot{E}_{20}$ & - & $\begin{array}{l}\dot{E}_{9}+\dot{E}_{18}+\dot{E}_{21} \\
-\dot{E}_{19}-\dot{E}_{20}\end{array}$ & $\frac{\dot{E}_{20}-\dot{E}_{18}}{\dot{E}_{9}+\dot{E}_{19}-\dot{E}_{21}}$ \\
\hline FWH 3 & $\dot{E}_{8}+\dot{E}_{20}$ & $\dot{E}_{21}+\dot{E}_{22}$ & - & $\begin{array}{l}\dot{E}_{8}+\dot{E}_{21} \\
-\dot{E}_{21}-\dot{E}_{22}\end{array}$ & $\frac{\dot{E}_{22}-\dot{E}_{20}}{\dot{E}_{8}-\dot{E}_{21}}$ \\
\hline Deaerator & $\begin{array}{l}\dot{E}_{7}+\dot{E}_{22} \\
+\dot{E}_{24}\end{array}$ & $\dot{E}_{23}$ & - & $\begin{array}{l}\dot{E}_{7}+\dot{E}_{22} \\
+\dot{E}_{24}-\dot{E}_{23}\end{array}$ & $\frac{\dot{E}_{23}}{\dot{E}_{7}+\dot{E}_{22}+\dot{E}_{24}}$ \\
\hline FWH 2 & $\begin{array}{l}\dot{E}_{6}+\dot{E}_{25} \\
+\dot{E}_{27}\end{array}$ & $\dot{E}_{24}+\dot{E}_{26}$ & - & $\begin{array}{l}\dot{E}_{6}+\dot{E}_{25}+\dot{E}_{27} \\
-\dot{E}_{24}-\dot{E}_{26}\end{array}$ & $\frac{\dot{E}_{26}-\dot{E}_{25}}{\dot{E}_{27}+\dot{E}_{6}-\dot{E}_{24}}$ \\
\hline FWH 1 & $\dot{E}_{5}+\dot{E}_{26}$ & $\dot{E}_{1}+\dot{E}_{27}$ & - & $\begin{array}{l}\dot{E}_{5}+\dot{E}_{26} \\
-\dot{E}_{1}-\dot{E}_{27}\end{array}$ & $\frac{\dot{E}_{1}-\dot{E}_{26}}{\dot{E}_{5}-\dot{E}_{27}}$ \\
\hline $\begin{array}{l}\text { Condense } \\
\text { Pump (P1) }\end{array}$ & $\dot{E}_{13}$ & $\dot{E}_{14}$ & $\dot{W}_{P \mathrm{I}}$ & $\begin{array}{l}-\left(-\dot{W}_{P I}\right) \\
+\dot{E}_{13}-\dot{E}_{14}\end{array}$ & $\frac{\dot{E}_{13}-\dot{E}_{14}}{\dot{W}_{P \mathrm{I}}}$ \\
\hline $\begin{array}{l}\text { Circulation } \\
\text { Pump (P2) }\end{array}$ & $\dot{E}_{23}$ & $\dot{E}_{25}$ & $\dot{W}_{P \mathrm{II}}$ & $\begin{array}{l}-\left(-\dot{W}_{P \mathrm{II}}\right) \\
+\dot{E}_{23}-\dot{E}_{25}\end{array}$ & $\frac{\dot{E}_{23}-\dot{E}_{25}}{\dot{W}_{P I I}}$ \\
\hline Overall plant & $\dot{\mathrm{E}}_{28}+\dot{\mathrm{E}}_{35}$ & $\dot{\mathrm{E}}_{32}$ & $\dot{W}_{n e t}$ & $\begin{array}{l}-\left(\dot{W}_{n e t}\right)+\dot{\mathrm{E}}_{28} \\
+\dot{\mathrm{E}}_{35}-\dot{\mathrm{E}}_{32}\end{array}$ & $\frac{\dot{W}_{n e t}}{\dot{\mathrm{E}}_{28}+\dot{\mathrm{E}}_{35}}$ \\
\hline
\end{tabular}

